Boston University School of Law

Scholarly Commons at Boston University School of Law

Faculty Scholarship

2001

Conjoined Twins: The Limits of Law at the Limits of Life

George J. Annas

Follow this and additional works at: https://scholarship.law.bu.edu/faculty_scholarship

Part of the Health Law and Policy Commons 
Legal Issues in Medicine

\section{Conjoined Twins - The Limits of LAW AT THE Limits OF Life}

\author{
George J. AnNAS, J.D., M.P.H.
}

C ONJOINED twins have been the subject of scientific exhibits, medical study, human curiosity, and even entertainment, but until the year 2000 , conjoined twins had never been the subject of a courtroom battle. A unique case that was the subject of two British court decisions deserves study. ${ }^{1}$ The case illustrates the difficulty of applying legal principles to unprecedented life-and-death decisions involving proposed medical interventions for children - particularly when parents and physicians disagree about what should be done.

The conjoined twins who were the subject of the court decisions are identified by the judges only as Jodie and Mary. They are the children of Michaelangelo and Rina Attard of the Maltese island of Gozo. The couple, who are Roman Catholic, came to England for medical care at about five months' gestation. The children, who were joined at the pelvis, their spinal columns on the same axis, with each having two arms and two legs, were born on August 8, 2000. The physicians saw no hope that the twins would survive for more than a year if they remained joined. They believed that if Mary (the weaker of the two and whose continued survival depended on sharing Jodie's circulatory system) was separated from Jodie, Mary would die, but Jodie would survive and do well. The parents refused to authorize the separation on the basis that it was wrong to choose between the lives of their two innocent children and that it was contrary to their religious beliefs. Physicians have historically honored the wishes of parents in such cases. ${ }^{2}$ In this case, however, the physicians decided to go to court for authorization to proceed with the separation over the objections of the parents.

In the United States, the decision of the parents would have been final unless the physicians or the state could have persuaded a judge that this was a case of child neglect. ${ }^{3}$ In Britain, the law is different: once a case is placed before a judge, the judge must decide what the welfare or best interests of the child require by exercising "an independent and objective judgment." The parents' wishes are just one piece of evidence to be considered in making this decision. The trial-court judge concluded that separation was in the best interests of both children and that separation was not a case of killing Mary but one of passive euthanasia in which her food and hydration would be withdrawn (by clamping off her blood supply from Jodie). ${ }^{1}$ The parents and the official solicitor, whose task was to represent Mary, appealed.

Each of the three judges on the appeals panel issued a separate opinion, as is customary in British courts. Although all the judges agreed with the trialcourt judge that the separation should be performed, none agreed with the legal reasoning of that judge, and none of the three judges on the appeals panel fully agreed with one another's legal reasoning. There are many explanations for these conflicting opinions, including the unprecedented nature of the dispute itself, a reliance on analogies that did not quite work, and a strong desire to authorize physicians to do what they think is best for their newborn patients.

\section{THE OPINION OF LORD JUSTICE ALAN WARD}

Lord Justice Alan Ward begins his analysis by noting that this "truly is a unique case" that "in a nutshell" involves killing the weaker twin, Mary (who would not have been viable had she been a singleton), to "give Jodie a life which will be worthwhile." Ward describes the physical condition of the twins in detail, quoting from medical reports that document, among other things, that Jodie has "an anatomically normal brain, heart, lungs and liver" and that she "appears to be a bright little girl," who is expected to be of "normal intelligence." Mary, on the other hand, is described by physicians as "severely abnormal," having a "primitive" brain, a very poorly functioning heart, and the absence of lung tissue. Ward concludes that Mary is incapable of surviving separately: "She lives on borrowed time, all of which is borrowed from Jodie. It is a debt she can never repay." He notes that separation will cause Mary's death (which will be quick and painless) and that a heart-lung transplant is not an option for Mary. ${ }^{1}$

Lord Justice Ward then turns to the question of why the court is involved at all, noting that although "every instinct of the medical team has been to save life where it can be saved," it would have been "perfectly acceptable" for the medical team and hospital to have respected the parents' wishes, even though this would have resulted in the death of both twins. But seeking the court's authorization of surgery is also acceptable in Ward's view, because "here sincere professionals could not allay a collective medical conscience and see children in their care die when they know one was capable of being saved. They could not proceed in the absence of parental consent. The only arbiter of that sincerely held difference of opinion is the court. Deciding disputed matters of life and death is surely and pre-eminently a matter for a court of law to judge."l

In analyzing the existing law, Ward strongly disagrees with the trial court. He states that it is "utterly fanciful" to classify the operation as "an omis- 
sion" of treatment (the failure to continue to provide nutrition) rather than as an active surgical intervention that will end Mary's life and that there is no way that killing Mary can be "in Mary's best interests." Instead, he concludes that the only proper legal path when there is a conflict of interest between conjoined twins is "to choose the lesser of two evils."

Ward condemns the parents' refusal to choose life for Jodie in dramatic terms: "In my judgment, parents who are placed on the horns of such a terrible dilemma simply have to choose the lesser of their inevitable loss. If a family at the gates of a concentration camp were told they might free one of their children but if no choice were made both would die, compassionate parents with equal love for their twins would elect to save the stronger and see the weak one destined for death pass through the gates." He goes on to say, "My heart bleeds for them. But . . . it is I who must now make the decision."

The decision, of course, seems to have been made once the condition of the two twins was described. But it still must be legally justified. Ward does this by accusing Mary of killing Jodie and thus making a decision to kill Mary justifiable homicide, a case of "quasi self defence": "Mary may have a right to life, but she has little right to be alive. She is alive because . . . she [parasitically] sucks the lifeblood out of Jodie. If Jodie could speak, she would surely protest, 'Stop it, Mary, you're killing me.'" Ward concludes that the physicians have a legal duty to Jodie, which gives them an obligation to act, and that "doctors cannot be denied a right of choice if they are under a duty to choose."

\section{THE OPINION OF LORD JUSTICE ROBERT BROOKE}

Lord Justice Robert Brooke horrified the parents when, in open court, he looked at pictures of the twins and asked, "What is this creature in the eyes of the law?" 4,5 His opinion, however, is more analytical. He agrees with Ward's analysis of family law but believes more is required to conclude persuasively that the operation that will kill Mary is lawful. The official solicitor, who opposed the separation, suggested nonetheless that the court might wish to develop new law that permitted such an operation if it was "proportionate and necessary" and "approved in advance by the court." Brooke essentially adopts this approach, and much of his opinion explores the legal doctrine of necessity.

The chief case that he examines is that of Regina v. Dudley and Stephens, a famous 1884 case that involved shipwreck and survival on the high seas by means of murder and cannibalism. ${ }^{6}$ In that case, a crew of four was sailing the yacht Mignonette from England to Australia when the ship came apart in a storm in the South Atlantic Ocean 2000 miles from land. The crew escaped in a lifeboat with only two cans of turnips. After 19 days the three senior members of the crew killed 17-year-old Richard Parker, the youngest and weakest member of the crew, and ate him in order to survive. They later explained that the point of killing him before he died naturally was to be able to drink his blood. ${ }^{7}$ After being rescued and returned to England, they were arrested and tried for murder - a charge they did not deny. Their defense was "necessity." The British courts rejected this defense, noting among other things that the boy did not threaten the rest of the crew and that the law could not justify the killing of "the weakest, the youngest, the most unresisting. . . . Was it more necessary to kill him than one of the grown men? The answer must be 'No."'6

Although so far rejected by British law, as this case illustrates, Brooke suggests that there may be circumstances in which the necessity defense should be allowed. He gives several examples. The first is the case of a mountain climber who must cut the rope holding him to another climber who has fallen, otherwise both will perish. The next is the 1987 sinking of the passenger ferry Herald of Free Enterprise near Zeebrugge, Belgium, in which almost 200 passengers drowned. An army corporal said that he and dozens of other people were in the water near the foot of a rope ladder and all were in danger of drowning. Their route to safety was blocked by a young man on the ladder who was paralyzed with fear. Eventually, the corporal ordered the man to be pushed off the ladder so that the others could climb to safety.

Two other examples had been used in the United States in 1977 by a rabbinical scholar who counseled a Jewish couple considering a similar operation on their conjoined twins who shared a heart. ${ }^{8}$ The rabbi reportedly said that if two men jump from a burning plane and the parachute of the second one fails to open, and he grabs the legs of the first man, the man whose parachute did open is morally justified in kicking the second man away to save himself because the man whose parachute did not open was "designated for death." Likewise, if a caravan is surrounded by bandits, and the bandits demand that a particular person be turned over to them or they will kill everyone, it is permissible to turn that person over because he has been "designated for death."

Many more legal authorities are quoted at length, but ultimately Lord Justice Brooke concludes that the objections to the necessity defense presented in the Dudley case of cannibalism on the high seas - who can judge this sort of necessity, and how can the comparative value of lives be measured? - are not applicable to the case at hand, because "Mary is, sadly, self-designated for a very early death." He also thinks there is no danger of the misuse of the necessity defense by physicians in other cases of conjoined twins because "there will be in practically every case the opportunity for the doctors to place the relevant facts 
before a court for approval (or otherwise) before the operation is attempted."

\section{THE OPINION OF LORD JUSTICE ROBERT WALKER}

Lord Justice Walker opens his opinion by describing this case as "tragic" and "unprecedented anywhere in the world." Although conjoined twins are unique, Walker insists that "there is no longer any place in the legal textbooks, any more than there is in the medical textbooks, for expressions (such as 'monster') which are redolent of superstitious horror. Such disparagingly emotive language should never be used to describe a human being, however disabled or dysmorphic." He nonetheless concludes that continued life joined to Jodie would "confer no benefit [on Mary] but would be to her disadvantage." Walker agrees with Brooke that the question of whether Mary can be lawfully killed for Jodie's sake rests on the issues of intention and necessity. Like Brooke he uses a series of analogies, but unlike him, Walker concludes that "there is no helpful analogy or parallel to . . . this case."

Ultimately, Walker determines that the doctors' duties to the twins are in conflict. Nonetheless, he believes the dilemma does not involve choosing "the relative worth of two human beings" but rather "undertaking surgery without which neither life will have the bodily integrity (or wholeness) which is its due." He believes that having her "bodily integrity," if only for a few seconds, is a benefit to Mary. He ultimately concludes that physicians would separate the twins not with the intent of killing Mary, but with the intent of making each twin whole and acting in the best interests of both. What seems to persuade Walker the most, however, is the testimony of the physicians: "Highly skilled and conscientious doctors believe that the best course, in the interests of both twins, is to undertake elective surgery in order to separate them and save Jodie."

\section{AFTERMATH}

The twins were separated six weeks after the opinion of the Court of Appeal was issued. ${ }^{9}$ Before the surgery was performed, there was further debate over which surgical team - the one with more experience or the one that brought the case to court - should perform the surgery. ${ }^{10}$ It was ultimately performed by the less experienced team. The physicians involved later told the press that they sought the court's approval because they were worried about being prosecuted for the murder of Mary. ${ }^{11}$ They continued to believe that separation was in the best interests of both twins (although it caused Mary's death), and when the final blood vessels connecting the twins were cut, an act that would result in the death of Mary, the two lead surgeons said they cut the blood vessels together, in silence and with "great respect." 5 The coroner's verdict stated simply that Mary died "following surgery separating her from her conjoined twin, which surgery was permitted by an order of the High Court, confirmed by the Court of Appeal." 12

The opinion of the appeals court has been praised. ${ }^{13}$ Jodie is doing well and may soon go home to Gozo with her parents. ${ }^{14}$ She will reportedly require extensive surgery over the next five years, most of which will be performed in Britain. ${ }^{9}$ Mary was buried on Gozo in January. ${ }^{14}$

\section{PROBLEMS WITH THE LEGAL ANALYSIS}

It is easy to see why all the judges involved characterized this case as unique and hoped that it would not set a precedent. The case seems to have been decided not on the basis of the law (which most of the judges found of little help) but on an intuitive judgment that the state of being a conjoined twin is a disease and that separation is the indicated treatment for it, at least if such treatment affords one of the twins a chance to live. The judges identified strongly with the physicians and had little empathy with the parents or their religious beliefs. I think all these factors led each judge to make problematic legal statements.

\section{Failure to Identify with the Parents}

Lord Justice Ward is the hardest on the parents, using the Sophie's Choice analogy of a parent at the gates of a concentration camp. The Nazi physician in charge of determining who is to go straight to the gas chambers and who can work or be used in medical experiments tells Sophie that both her children will be killed if she does not choose one to save. ${ }^{15}$ Ward insists that a parent in this situation must choose. Sophie, of course, did choose, although she ultimately lost both children to the Nazis and killed herself because she was unable to live with her decision. ${ }^{15}$ Ward's reasoning, at the heart of his analysis, is troubling in at least two respects. The first is his conclusion that parents must choose which child will die when only one can be saved. We would not condemn a parent for making this terrible choice, but neither should we condemn a parent for refusing to make it. For example, if a father jumps from a burning plane holding his two children, one in each arm, and then begins to lose his grip on both and realizes that he will drop them both if he does not drop one to save the other, we would not fault him for dropping one. Neither, I believe, should we fault a parent for refusing to choose and trying to hang on to both children for as long as possible. Second, and more disturbing with respect to the concentration-camp example, is the question of who the judge thinks is in the role of the Nazi physician. Ultimately, Ward concludes that it is the British physicians who "should be given the right of choice," but he also seems to place himself in that role, saying, "it is I who must now make the 
decision." Of course, Ward is not choosing to kill both twins, and perhaps he sees nature as the Nazis. Nonetheless, it is unsettling to have a British judge rely on what might be termed "concentration-camp ethics" to reach a decision.

Lord Justice Ward insists that the law requires him to do what is in the "best interests" of the children and that British law prohibits the use of the doctrine of "substituted judgment" (determining what an incompetent person would decide if he or she were capable of making a decision). Nonetheless, his primary argument turns out to be based on this doctrine: in colorful language he likens Mary to a parasite who is "poisoning" Jodie and sucking out her "lifeblood." He knows what Jodie would decide if she could decide: "If Jodie could speak, she would surely protest, 'Stop it, Mary, you're killing me.'" But the problem with using substituted judgment in the case of very young children is that we have no way of knowing what they would say and tend to speculate on the basis of our own adult values. For example, Jodie could equally well say to her identical and attached twin that "I love you as myself and will do everything, including sacrificing my life, to keep you alive as long as possible." Likewise, Mary might reasonably say to Jodie, "You are my identical twin, and because I love you, I'm willing to die so that you can live, since this is the only chance for my genes to be transmitted to the next generation." Each twin might also, of course, consider the other twin to be an integral part of herself, a view that would preclude separation. Any of these hypotheses is plausible, but made-up monologues cannot take the place of legal analysis.

\section{Problems with Analogies}

Justice Brooke's opinion is problematic because in my view he has not properly interpreted the analogies he uses. His reliance on the necessity defense, for example, is ultimately based almost exclusively on the two analogies that were reportedly used by a rabbi in counseling a Philadelphia couple in a similar situation in 1977: the men jumping from the burning plane and the caravan surrounded by bandits. In each case, the necessity defense is said to be appropriate because the person killed was "designated for death," a phrase Brooke adopts as his primary justification for killing Mary to save Jodie. In fact, he goes further, concluding, "Mary is, sadly, self-designated for a very early death."

There are two problems with this conclusion. First, Mary did not designate herself for anything, she was simply born and survived. But even the simple conclusion that one can be "designated for death" may not be a proper interpretation of the two analogies. The description of the cases was drawn from an article I wrote in 1987, and I used a 1977 newspaper report as my own source. $8,16,17$ More important than what might have been lost in the retelling, how- ever, is that expert commentary on these examples has since been published, and the court seems unaware of it.

A leading U.S. rabbinical authority, Rabbi J. David Bleich, has written that these two stories are not examples of instances in which a person is "designated for death." 18 Instead, the example involving the parachutists is more correctly thought of as a case of pursuit, in which the first man's kicking off of the man who is clinging to him is justified by the fact that that man's intentional actions would otherwise kill him. With respect to the second example, Rabbi Bleich argues that the caravan is justified in turning over the named person only if that person is guilty of some crime; if the person is innocent, he may not be given up to face certain death. Others have suggested that in a similar situation the group could lawfully agree to use a random device, such as drawing straws, to decide who would be sacrificed for the good of the group. ${ }^{19,20}$

Rabbi Bleich does, nonetheless, offer Lord Justice Brooke another justification for his conclusions. Bleich believes that there may be exceptional circumstances in which one conjoined twin can be judged a pursuer of the other: "If the heart can be shown to belong to one twin exclusively, the second is, in effect, a parasite . . . [and having] no claim to the heart, is then quite literally a pursuer." 18 Pursuers must be stopped before they kill, and self-defense would have provided Brooke with a much sounder rationale than the "designated for death" approach.

\section{Problems with Conjoined Twins Themselves}

Lord Justice Walker's opinion is, I think, most notable in attempting to consider the conjoined twins as both a single entity and two persons. Walker wants to discourage the use of terms such as "monster" (and probably "creature" as well) to describe conjoined twins. Nonetheless, he speaks of them not as one entity, but as two separate "innocent children" and believes the "court must consider the welfare of each." The problem is that once the twins are separated verbally, it is only a matter of time before they will be separated surgically. Walker sees these conjoined twins as a serious, lethal anomaly that must be medically corrected so that at least one of the twins can appear normal. In this regard Walker seems correct in concluding, "in truth there is no helpful analogy or parallel to the current situation." He thus seems to find the condition of being a conjoined twin, at least when one could live if the other were killed, itself adequate justification for separation. That is why he can conclude, with the physicians, the trial-court judge, and Lord Justice Brooke, that separation would be in the best interests of both children. Stated another way, three of the four judges believed that Mary was better off dead than continuing to live for a few months as a conjoined twin. 


\section{LESSONS}

Perhaps the most important lesson of the case of Jodie and Mary is that there are severe limits to the law in making unprecedented, complex, life-and-death decisions. The most important shortcoming of the decision of the judges is that it did not rest on any legal principle. That is why if the circumstances of this case were to be duplicated tomorrow at the Great Ormond Street Hospital for Children in London, the physicians involved could, on the basis of the reasoning of this case (and contrary to its conclusion), decide to follow the wishes of the parents and let both twins die. The conclusion of Lord Justice Ward that it would have been "perfectly acceptable" for physicians to decide either way must be wrong: if Mary is a pursuer who is killing Jodie, saving Jodie's life (and that of others in her situation) by ending Mary's life must be mandatory. The court's ruling that physicians can do whatever they think is best (with the court's prior approval) is no legal rule at all. Nor is it true that there will almost always be ample time to seek court review in cases such as this. ${ }^{10,21}$

Closely related is the question of the court's role in similar cases. Is it to determine whether a particular course of action, chosen by both parent and physician, is legally permissible, or is it to determine whether a particular medical intervention is required by law? The first role seems reasonable; the second seems justified only in cases in which the failure to act (on the part of either parent or physician) is child neglect. In this regard, had Jodie been a singleton, her parents might well have been justified in refusing to consent to three or four years of complicated surgical procedures with an uncertain outcome on the basis that they did not believe the burdens of these interventions on Jodie could be justified by the expected outcome even if the physicians believed the operation was in her best interest. ${ }^{22}$

My own view is that in this case, it would have been better had the physicians not sought court intervention, or if they had, for the trial court to have refused to hear the case and to have instructed the physicians that they must obtain the parents' consent before separating the twins. I would have liked to have had the parents agree to the separation (since giving Jodie a chance to live at the cost of cutting Mary's life short does seem the lesser of two evils), but I do not believe the case for separation is so strong that it demands that the authority to make the decision about the medical care of their children be taken away from the parents.

\section{REFERENCES}

1. Re A (children), (2000) 4 All ER 961.

2. O'Neill JA, ed. Pediatric surgery. 5th ed. St. Louis: Mosby-Year Book, 1998:1925-38.

3. Rosato JL. Using bioethics discourse to determine when parents should make health care decisions for their children: is deference justified? Temple L Rev 2000;73:1

4. Cullen K. In London, an agonizing decision. Boston Globe. September 11, 2000:Al, A8.

5. Wells M. Surgeons speak of life-death op on twins. Guardian (London). December 8, 2000:13.

6. Regina v. Dudley \& Stephens, (1884) 14 QBD 273

7. Simpson AWB. Cannibalism and the common law: the story of the trag ic last voyage of the Mignonette and the strange legal proceedings to which it gave rise. Chicago: University of Chicago Press, 1984.

8. Annas GJ. Siamese twins: killing one to save the other. Hastings Cent Rep 1987;17:27-9.

9. Laville S. Mary was freed by death, says father. Daily Telegraph (London). December 7, 2000:1.

10. Spitz L, Kiely E. Success rate for surgery of conjoined twins. Lancet 2000;356:1765.

11. British surgeon reflects on decision to let Siamese twin die. Toronto Star. January 7, 2001:1.

12. Bunyan N. Doctors 'had no option but to separate twins.' Daily Telegraph (London). December 16, 2000:9.

13. Smith AM. The separating of conjoined twins. BMJ 2000;321:782.

14. Cramb A. Village children mourn as Siamese twin is laid to rest. Daily Telegraph (London). January 20, 2001:3.

15. Styron W. Sophie's choice. New York: Random House, 1979.

16. Drake DC. The twins decision: one must die so one can live. Philadelphia Inquirer. October 16, 1977.

17. Thomasma DC, Muraskas J, Marshall PA, Myers T, Tomich P, O’Neill JA. The ethics of caring for conjoined twins: the Lakeberg twins. Hastings Cent Rep 1996;26:4-12.

18. Bleich JD. Conjoined twins. Tradition 1996;31:92-125.

19. U.S. v. Holmes, 26 F. 360 (E.D. Pa. 1842).

20. Fuller L. The case of the Speluncean explorers. Harv L Rev 1949;62: 616.

21. Norwitz ER, Hoyte LP, Jenkins KJ, et al. Separation of conjoined twins with the twin reversed: arterial-perfusion sequence after prenatal planning with three-dimensional modeling. N Engl J Med 2000;343:399402.

22. Re T, (1997) l All ER 906.

Copyright (C) 2001 Massachusetts Medical Society. 